\title{
CONSIDERATIONS REGARDING THE MEASURE OF OBTAINING DATA GENERATED OR PROCESSED BY PROVIDERS OF PUBLICLY AVAILABLE ELECTRONIC COMMUNICATIONS NETWORKS, DETAINED BY THEM, IN THE CONTEXT OF DECISION NO. 440/2014 OF THE CONSTITUTIONAL COURT
}

\author{
A. S. Uzlău C. M. Uzlău
}

\section{Andreea Simona Uzlău}

Faculty of legal and administrative sciences,

"Dimitrie Cantemir" Christian University of Bucharest

*Correspondence: Andreea Simona Uzlău, "Dimitrie Cantemir" Christian University of Bucharest, Splaiul Unirii Street, No. 146, Bucharest, Romania

E-mail: stoicaandreea76@yahoo.com

\section{Marilena Carmen Uzlău}

Faculty of Economics

Hyperion University of Bucharest

*Correspondence: Marilena Carmen Uzlău, Hyperion University of Bucharest, Călăraşilor Street, No. 169, Bucharest, Romania

E-mail: carmen_uzlau@yahoo.com

\begin{abstract}
The work analyzes the practical effects in national plan of the preliminary judgment delivered by the Court of Justice of the European Union concerning Directive 2006/24/EC on the retention of data generated or processed by providers of networks and electronic communications services for the public and amendment of Directive 2002/58/EC and of decision of the Constitutional Court No. 440 of 8 July 2014
\end{abstract} procedure

Key words: retention of data, special research methods, the new Code of criminal

\section{Introduction}

The study analyzes the practical effects in national plan of the preliminary judgment delivered by the Court of Justice of the European Union concerning Directive 2006/24/EC on the retention of data generated or processed by providers of networks and electronic communications services for the public and amendment of Directive 2002/58/EC and of decision of the Constitutional Court No. 440 of 8 July 2014.

The analysis is conducted from the perspective of criminal procedure legislation and is structured around the main themes arising from this topic, namely the judgment of the Court of Justice of the European Union, the internal assessment of specific consequences of the invalidation of the directive, the assessment of the consequences of the decision No. 440/2014 over domestic laws. The study aims to analyze the institution, in order to facilitate understanding and deepening of it, and to suggest any necessary legislative changes.

\section{General context}

By the decision of the Court of Justice of the European Union dated on 8 April 2014, rendered in joined cases C-293/12 (Digital Rights Ireland) and C-594/12 (Seilinger and others), with the object of interlocutory decision requests issued pursuant to art. 267 of the 
Treaty on European Union, the Directive 2006/24/EC on the retention of data generated or processed by providers of networks and electronic communications services for the public and amendment of Directive 2002/58/EC was declared invalid.

The Court found that "the obligation imposed by articles 3 and 6 of Directive 2006/24 to the providers of publicly available electronic communication services or of public communications networks to retain data for a certain period, related to a person's private life and his communications, as well as those set out in article 5 of this directive, constitute per se an interference with the rights guaranteed by article 7 of the Charter of fundamental rights of the European Union".

In addition, the Court also found that Directive 2006/24 does not provide clear and precise rules governing the extent of interference in fundamental rights enshrined in articles 7 and 8 of the Charter and does not provide sufficient guarantees to ensure the effective protection of data stored against the risks of abuse, as well as any access and any use of such data. Therefore, this directive "contains an interference in these fundamental rights, which is of great magnitude and gravity in the Union legal order, without such interference to be clearly framed by provisions which may ensure that it is effectively limited to the minimum necessary."

This ruling, through which it was declared the invalidity of Directive 2006/24/EC, deprived the legal effects of the legislative act of the European Union from the date of its entry into force.

\section{Evaluation of specific internal consequences of the invalidation of the directive}

The judgment of the Court of Justice of the European Union mentioned above is mandatory not only for the Court which solves the dispute in which the preliminary inquiry has been made, but also for other national courts which are notified with a similar problem.

It has not yet produced any direct effect on national legislation, legislative authority not being obliged automatically and immediately to repeal the normative acts which have transposed the directive 2006/24/EC.

In our country, this transposition was achieved by the adoption of Law no. 82/2012 concerning the retention of data generated or processed by providers of publicly available electronic communications networks and providers of publicly available electronic communications services, as well as for the modification and completion of the Law no. 506/2004 on the processing of personal data and the protection of privacy in the electronic communications sector. ${ }^{1}$

In addition, the new Code of Criminal Procedure regulates, in article 152, the getting of data generated or processed by providers of publicly available electronic communications networks and/or providers of publicly available electronic communications services, other than the content of communications, and retained by them.

\section{Constitutional Court decision no. 440/2014}

By decision no. 440/2014 ${ }^{2}$, the Constitutional Court upheld the plea of unconstitutionality and found that the provisions of Law no. 82/2012 concerning the retention of data generated or processed by providers of publicly available electronic communications networks and providers of publicly available electronic communications services, as well as for the modification and completion of the Law no. 506/2004 on the processing of personal data and the protection of privacy in the electronic communications sector are unconstitutional.

\footnotetext{
${ }^{1}$ Republished in Official Gazette No. 211 of 25 March 2014.

${ }^{2}$ Published in m. Of. nr. 653 of 4 September 2014.
} 
At the same time, the plea of unconstitutionality in respect of the provisions of art. 152 of the new Code of criminal procedure, regarding the claims directed, was rejected as unfounded.

The motivation of the decision stated, in essence, that Law no. 82/2012 represents the transposition into national law of Directive 2006/24/EC of the European Parliament and of the Council of 15 March 2006 on the retention of data generated or processed in connection with the provision of electronic communications services available to the public or public communications networks and amending Directive 2002/58/EC. However, Directive 2006/24/EC was declared invalid by the judgment of the Court of Justice of the European Union on 8 April 2014, delivered in joined cases C-293/12, Digital Rights Ireland Ltd v. Minister for Communications, Marine and Natural Resources and others, and C-594/12, Kärntner Landesregierung and others. By the decision mentioned, the European Court found that the analyzed directive infringes the provisions of article 7, art. 8 and article 52 para. (1) of the Charter of fundamental rights of the European Union.

Analyzing the provisions of Law no. 82/2012, the Court noted, firstly, that the interference in the fundamental rights relating to personal, family and private life, secrecy of correspondence and freedom of expression is on a large-scale and should be regarded as particularly serious, and the circumstance that preservation of data and their subsequent use are carried out without the subscriber or registered user to be informed of this is likely to print in the consciousness of the subjects feeling that their private lives are under constant surveillance.

Specifically, the envisaged data lead to very precise conclusions on the privacy of persons whose data have been kept, conclusions that may concern the customs of everyday life, the places of permanent or temporary residence, daily movements or other movements, activities, social relations of these persons and social environments frequented by them. However, such a limitation of the exercise of the right to personal, family and private life and secrecy of correspondence, as well as freedom of expression must take place in a clear, predictable and obvious manner, so, as far as possible, the event of arbitrariness or abuse of the authorities in this area to be avoided.

Also the criticized law doesn't contain clear and precise rules about the content and implementation of the measure of retention and use of data, so that persons whose data have been kept to receive sufficient guarantees to ensure effective protection against abuse and any access or illicit use.

It was noted, however, that owing to the nature and specificity of it, since the legislator finds necessary retention and storage of data, by itself, only this operation does not conflict with the right to personal, family or private life or correspondence secrecy. Neither the Constitution nor the case-law of the Constitutional Court do not prohibit preventative storage, without a certain occasion, of traffic data and location information, under condition that the access to these data and their use to be accompanied by guarantees and to respect the principle of proportionality.

In terms of access of judicial bodies and other State bodies involved in the field of national security to the data stored, the Court found that the law does not provide the necessary guarantees of protection of the right to personal, family and private life, correspondence secrecy and of the freedom of expression of persons whose data are accessed.

Thus, the prosecution is required to comply with the provisions of article $152 \mathrm{NCCP}$, this obligation not being intended for State bodies with powers in matters of national security, which can access the data in accordance with the "special laws in the matter", as provided for in art. 16 para. (1) of Law no. 82/2012. Therefore, only the request made by the prosecution to the providers of publicly available electronic communications networks and providers of 
publicly available electronic communications services, to send the data retained, is subject to prior authorization of the judge of freedoms and rights.

Requests for access to data retained for the use in the purpose prescribed by law, formulated by the State bodies with powers in matters of national security, are not subject to authorization or approval of the Court, thereby depriving the guarantee of effective protection of data stored against the risks of abuse, as well as against any access to any illicit uses of such data. Circumstance is likely to constitute an interference with the fundamental rights to personal, family and private life, correspondence secrecy and, therefore, contrary to the constitutional provisions enshrining and protecting those rights.

Accordingly, taking into consideration the definitive and compulsory nature of its decisions, the Court pointed out that, since the publication of the decision of the Constitutional Court of Romania, the providers of publicly available electronic communications networks and providers of publicly available electronic communications services no longer have any obligation, and no legal possibility to retain data generated or processed in connection with their work and to put them at the disposal of the judicial organs and those with powers in matters of national security. By exception, it may be retained by these providers only data necessary for billing or interconnection payments or other data processed for marketing purposes, only with the prior consent of the person whose data are being processed, as provided for in Directive 2002/58/EC, currently in force.

Correlatively, pending adoption by Parliament of a new law on the retention of data, consistent with the provisions and constitutional requirements, as they have been identified in this decision, the judicial authorities and State bodies involved in the field of national security no longer have access to data which have been detained and already stored on the basis of Directive 2006/24/EC and the Law no. 82/2012 for use in the activities defined by art. 1 paragraph (1) of Law no. 82/2012. In addition, judicial organs and those with powers in matters of national security do not have legal and constitutional basis for accessing and using the data retained by the providers for invoicing, payments for interconnection or other commercial purposes, and to use them in the context of prevention activities, research, discovery and prosecution of the serious offences or for solving cases with missing persons or for the execution of a warrant of arrest or execution of a penalty, precisely because their different character, nature and purpose.

With regard to the provisions of art. 152 of the new Code of criminal procedure, the Court noted that the criticized text does not regulate the procedure to restraint and storage data generated or processed by providers of publicly available electronic communications networks and providers of publicly available electronic communications services, to retain data generated or processed, but sets out only the procedure for prior authorization by the judge of the rights and freedoms of the request addressed to those providers by the prosecution, for access and use data retained.

At the same time, it has been shown that, in terms of the lack of a law regulating the procedure to retain and store data, the article 152 of the new Code of criminal procedure remains without a practical applicability, the text following to become incident immediately after a new law concerning the retention of data is passed.

In accordance with the provisions of art. 147 of the Constitution of Romania, republished:

"(1) The provisions of laws and ordinances in force and those of the regulations, established as unconstitutional, cease their legal effect within 45 days since the publication of the decision of the Constitutional Court if, in the meantime, the Parliament or the Government, as the case may be, do not agree with the provisions of the Constitution, the unconstitutional regulations. During this period, provisions recorded as unconstitutional are suspended by law. 


\section{A. S. Uzlău C. M. Uzlău}

(4) The decisions of the Constitutional Court shall be published in the Official Gazette of Romania. Following its publication, the decisions are generally binding and only have power for the future."

In relation to these laws, the Constitutional Court's decision, handed down on 8 July 2014, has produced general binding effects starting from the date of its publication in the Official Gazette, date from which the provisions of Law no. 82/2012 are suspended by law, for a period of 45 days. After this period, if the provisions of this law are not in accordance with the Constitution of Romania, the normative act mentioned ceases its effects.

\section{procedure \\ 4. The pursuit method provided by art. 152 of the new Code of criminal}

The probation method provided by art. 152 of the new Code of criminal procedure do not fall within the concept of technical supervision and cannot be provisionally authorized by the prosecutor in case of emergency. ${ }^{3}$

The pursuit method provided by art. 152 of the new Code of criminal procedure is very shortly regulated, the text from the law making reference only to the fact that the judge of the rights and freedoms authorizes it, without determining the procedure.

The article 152 of the new Code of criminal procedure sends to the special law in matter, namely the Law no. 82/2012 concerning the retention of data generated or processed by providers of publicly available electronic communications networks and providers of publicly available electronic communications services.

As a result, regarding the decision of the Constitutional Court, the measure of obtaining data generated or processed by providers of publicly available electronic communications networks or providers of publicly available electronic communications services, other than the content of communications, and retained by them in relation to the current provisions of art. 152 of the new Code of criminal procedure will acquire the practical efficiency in the context of a subsequent legislative change.

By declaring the Law no. 82/2012 unconstitutional by the Constitutional Court and in the absence of the adoption at European level of a new legislative act of the European Union concerning the retention of data generated or processed by providers of networks and electronic communications services for the public, it has been created a legal vacuum with possible negative consequences on the activities of criminal investigation bodies, courts and State bodies involved in the field of national security.

Thus, being given the fact that the provisions of article 152 of the new Code of criminal procedure were expressly maintained in force by the Constitutional contentious Court, a legislative intervention is necessary to define the limits within which communication data can be obtained by the prosecution.

4.1. Regulation object. The provisions of Law no. 82/2012 gave the possibility for the prosecution to ask, with the approval of the judge of rights and freedoms, the providers of communications the data they store, other than the content of conversations or communications. According to the article. 1 of the law referred to, the providers of publicly available electronic communications networks and providers of publicly available electronic communications services had an obligation to retain and communicate to criminal investigation bodies, under the conditions laid down in the Code of criminal procedure, data traffic and location of natural and legal persons, as well as the data needed to identify a

\footnotetext{
${ }^{3}$ M. Udroiu, Procedură penală. Partea generală. Noul Cod de procedură penală, ALL Beck Publishing House, Bucharest, 2014, p. 338.
} 
subscriber or a registered user. These data do not include the content of such communication or information accessed while using electronic communications network.

According to the provisions of Law no. 82/2012, the list of data that was supposed to be retained by electronic communications providers was quite broad-art. 3-10 of the $1 \mathrm{aw}^{4}$-, allowing criminal investigation bodies the identification of all elements which could determine a person's identity, its location, the traffic he carried, etc. The data were stored by communications service providers for a maximum period of 6 months, during which they could be requested by the judicial authorities. For the efficiency of the measure, in an upcoming legislative change it will be necessary to provide for the categories of data that may be subject of it.

4.2. The offences for which authorization may be required. In the case of data stored by communications service providers, the offences were provided by article. 2 para. (1) let. e) of Law no. 82/2012. Accordingly, in order for the measure to acquire practical efficiency, it is necessary to mention, even in the article 152 of the new Code of criminal procedure, the categories of serious offences for which the measure may be ordered.

It is found in the research methods a lack of standardization of the list of offences for which it may be ordered these probation procedures, practical for each activity, list is different, the differences being small in the methods covered in the Code of criminal procedure, but considerable in the norm of reference, as is the case for data storage pursuant to art. 152 of the new Code of criminal procedure.

4.3. Procedure to be followed. For the issue of the warrant for technical surveillance for the purpose of intercepting conversations and communications, the procedure to be followed and the conditions to be issued are those provided by art. 139 of the new Code of criminal procedure.

For the approval of the request by the public prosecutor of the data stored by communications service providers, the procedure is similar to that of the technical surveillance, with a few exceptions. Thus, the conditions for the approval of the request are:

a) authorization is given by the judge of rights and freedoms;

b) the application of the Prosecutor shall be made in the course of criminal prosecution;

c) conditions for the approval of the request:

- there is a reasonable suspicion of committing a serious infringement, as defined in article 2 para. (1) let. e) of Law no. 82/2012;

- there are grounds to believe that the data requested are evidence;

d) the application shall be solved within 48 hours in the Council Chamber, by a reasoned closing.

To authorize the request of data transmission, the legislature departed from the rules laid down both for technical surveillance, and for research methods, because there are no longer set as conditions the proportionality, the necessity of the evidence and the failure to obtain it by other means. It was considered, wrongly we believe, that the intrusion into the private life of a person is minimal, because the required data does not concern the contents of transmissions; however, as noted in the decision of the Constitutional Court and referred to above, these data, if related to each other, can be a pretty clear portrait of the life of a person-

\footnotetext{
${ }^{4}$ The data necessary to trace and identify the source of a communication; the data necessary to identify the destination of a communication; the data necessary to determine the date, time and duration of the communication; the necessary data for identification of the type of communication; the data necessary for the identification of the user's communication equipment or devices serving as user equipment; data necessary to identify the location of mobile communication equipment.
} 
who speaks with on the phone, how often, where he connects or the itinerary followed in certain periods, what sites he visits and how often.

Providers of publicly available electronic communications networks and providers of publicly available electronic communications services that work with the criminal prosecution bodies have the duty to keep the secrecy of the operation performed. ${ }^{5}$

4.4. Getting data during the trial. In practice of the courts arose a situation that is unique to the rule according to which the prosecutor asks the authorization of the judge of rights and liberties during criminal prosecution. Specifically, it is given the question of what is the solution where, in the course of administering the probation in court, it comes the need to check the date of the first phone call, and the itinerary followed by the injured party, in order to determine specifically whether, given his physical condition, he was able to travel a certain distance within an hour.

Through its provisions, art. 152 of the new Code of criminal procedure refers only to the case Prosecutor which will require the authorization of the judge of rights and freedoms. Also, neither for other methods of surveillance and investigation there has not been provided the hypothesis that the judge of the case may order, during the trial, the use of probation procedures. The assumptions where there is necessary the use of special methods of surveillance and investigation are rare, evidences being already gathered when the Court is notified with the judgment of the case. Moreover, for a number of methods, confidentiality of operations is essential to be effective, and at the end of prosecution the subject must be informed of the activities. These considerations are valid for technical surveillance, due to the fact that, to be effective, the person concerned does not have to know the measures ordered against him, but some investigation methods, such as getting the listing of phone calls, location, data transmission on a given period of time, financial data transmission, may constitute evidence in the criminal trial, helping to establish the truth. Furthermore, if these evidences were requested by the defendant in the course of criminal proceedings and were not administered by the judicial bodies, it is all the more necessary as they may be required and brought in the probation.

Another argument in support of the idea that the judge of the case may, in the course of the judicial investigation, to order ex officio the administration of any evidence he considers necessary, evidence which during prosecution would have required the authorization of a judge of rights and freedoms, is based on the rule that who may more may less. As long as the judge of the rights and freedoms may authorize action against the suspect, even more a judge sworn with the judgment of the case may require and administrate, when deemed necessary for forming his belief, the evidence which may lead to finding out the truth.

\section{Conclusions}

The study analyzes the practical effects in national plan of the preliminary judgment delivered by the Court of Justice of the European Union concerning Directive 2006/24/EC on the retention of data generated or processed by providers of networks and electronic communications services for the public and amendment of Directive 2002/58/EC and of decision of the Constitutional Court No. 440 of 8 July 2014.

The analysis is conducted from the perspective of criminal procedural legislation and is structured around the main themes arising from this topic, namely the judgment of the Court of Justice of the European Union, the assessment of specific consequences on internal plan of the invalidation of the directive, the assessment of the consequences of the decision no. 440/2014 over domestic laws. The study aims to analyze the institution, in order to

\footnotetext{
${ }^{5}$ Corina Voicu, Andreea Simona Uzlău, Georgiana Tudor, V. Văduva, Noul Cod de procedură penală. Ghid de aplicare pentru practicieni, Editura Hamangiu, București, 2014, p. 134.
} 
facilitate understanding and deepening of it, as well as to suggest any necessary legislative changes.

Without issuing the claim that through our intercession the theme has been addressed fully, we appreciate that through advanced theoretical considerations we have managed to bring into focus the main issues which will arise from the application of the institution and to identify possible preferable legislative solutions.

\section{Bibliography}

1. M. Udroiu, Procedură penală. Partea generală. Noul Cod de procedură penală, ALL Beck Publishing House, Bucharest, 2014;

2. Corina Voicu, Andreea Simona Uzlău, Georgiana Tudor, V. Văduva, Noul Cod de procedură penală. Ghid de aplicare pentru practicieni, Hamangiu Publishing House, Bucharest, 2014. 